\title{
THE SOCIO-ECONOMIC DIMENSION AND ITS INFLUENCE TOWARDS THE LEVEL OF TECHNOLOGY APPLICATION FOR SHRIMP FARMS IN PARIGI MOUTONG, CENTRAL SULAWESI, INDONESIA
}

\author{
Yasin Muhammad \\ Faculty of Economics, University of Alkhairaat, Central Sulawesi, Indonesia \\ E-mail: yasinmel18@gmail.com
}

\begin{abstract}
The research was conducted to identify the influence of socio-economics dimension, which consisted of financial capital, frequency of training on agriculture, and product price as well as their implication towards the level technology application in and productivity of shrimp farm. The research methodology was survey and the survey was conducted in Parigi Moutong Regency, Central Sulawesi, Indonesia. The sampling method was "two stage cluster sampling". The number of samples was 54 respondents who live in four villages in three different subdistricts, namely Dolago and Boyantongo in South Parigi Subdistrict, Malakosa in Balinggi Subdistrict and Sausu Piore in Sausu Subdistrict. The data collection methods were questionnaire and documentation from secondary source. The data analysis method was multiple linear regression. The analysis indicated that financial capital, frequency of training on agriculture, and sales price had simultaneous influence towards technology application. Frequency of training on agriculture had partial, significant influence towards technology application level significantly, but the other factors did not.
\end{abstract}

\section{KEY WORDS}

Financial capital, frequency of extension, salling price, technology aplication, shrimp farms.

Indonesia is a maritime country famous for its fish and marine biota. Its strategic geographical location and abundant marine resources become competitive advantage for Indonesia and potentials to develop their national economy. Science, technology and professional management are three requirements to maximize this resource-based industry (Wicaksana, 2003: 1).

The main reasons that makes fisheries an important commodity in Indonesia are (1) Indonesian seas have abundant fish; (2) there is an increasing trend in the contribution of the fisheries sub-sector towards the agricultural sector; and (3) fish are nutritious food with high economic value (Dahuri; 2002).

Shrimp is a type of marine resource that has the highest potential for export and generating foreign exchange for the country. More than 50 percents of Indonesian foreign exchange come from shrimp. Thus, shrimp industry is a promising industry to develop. Long economic recession did not seem to influence shrimp price and the demand for this commodity kept increasing.

In 1980 , there were only 182,400 ha of shrimp farms in Indonesia; the number increased to 344,759 ha in 1999 and the potentials are 866,550 ha. These numbers show that only $39.78 \%$ of the potential areas are used as shrimp farms (DKP, 2005). Furthermore, it is estimated that Indonesian fishermen can catch up to 74,000 tons of shrimp per year, and have been able to catch around 70,000 tons per year so far. In other words, the fishermen have been able to catch 95\% of the marine potentials (Amri, 2003: 3).

Optimum shrimp cultivation and fishing have positive impact towards Indonesian foreign exchange. In 2015, most (approximately $70 \%$ ) of the tiger shrimp farms in Indonesia is run based on conventional methods. Production volume of these tiger shrimp farms is 0.35 tons/ha/mt.

An area that has the highest potential for shrimp cultivation is Parigi Moutong, one of 13 municipalities/cities in Central Sulawesi, Indonesia. Shrimp farms in Parigi Moutong are run based on traditional method and their average production is 0.175 tons $/ \mathrm{ha} / \mathrm{mt}$. One 
method to increase economic contribution of tiger shrimp commodity in Parigi Moutong is to conduct an in-depth study to determine what causes lacking amount of technology application in the tiger shrimp farms and find out solutions to increase technology application in the cultivation area. This study helps shrimp farmers managing their business in the future while increasing production and their household income. Therefore, it is important to investigate how much influence socio-economic dimensions have towards technology application for tiger shrimp farm in Parigi Moutong.

Statement of Problem. Based on the background of the study, the statements of problem are described as follows:

- Do socio-economic dimensions, which consist of financial capital, frequency of training on agriculture and sales price, have simultaneous influence towards level of technology application in shrimp farm in Parigi Moutong?

- Do socio-economic dimensions, which consist of financial capital, frequency of training on agriculture and sales price, have partial influence towards level of technology application in shrimp farm in Parigi Moutong?

Theoretical Framework. According to Gomes (as cited in Sulaeman 2005: 30), in general there are four factors that influence agricultural production, namely: (1) physical environmental factors, for example solar energy, soil fertility, topography, water and climate, (2) socio-economic environmental factors, such as government policies, facilities and infrastructure, economic instruments, institutions and economic structure of a community, (3) individual characteristics of farmers, and (4) technology. These factors are also applicable for aquaculture, for example topography, pond fertility, brackish water supply, ecosystems, and climate play a role in the success of tiger shrimp cultivation (Suyanto, et.al., 2003: 42).

In aquaculture, some factors are directly related to production while some others are not. Smith (1986, as cited in Ismuha 1988: 9) stated that factors that have direct influence towards production are stocking density and supplementary food, while those that are not directly related to production are fertilizers and pesticides. However, application of fertilizers and pesticides is directly related to production. Ismuha's study (1988) discussing intensification of tiger shrimp farm in Aceh Besar reported that production depends on factors such as environment (soil $\mathrm{pH}$, salinity), stocking density, supplementary food, fertilizer, pesticides, labor, management and applied technology.

The finding of an experiment in Jeneponto, South Sulawesi in 2005 showed that application of technology called Intensifikasi Pembudidayaan (Inbud) in 0.4 hectare-width ponds where 50,000 shrimp fries were spread and kept for 4 months, produced $750 \mathrm{kgs}$ of fresh shrimp or $25-30$ shrimps $/ \mathrm{kg}$.

Objective of the Study. The objective of the study is to identify influence of socioeconomic dimensions, which consist of financial capital, frequency of training on agriculture, and sales price towards technology application in tiger shrimp farm in Parigi Moutong, Central Sulawesi, Indonesia.

\section{METHODS OF RESEARCH}

The study was conducted to describe how much influence economic dimensions had towards technology application for shrimp farms in Parigi Moutong, Central Sulawesi. There are 8 (eight) sub-districts in Parigi Moutong where shrimp farms are located.

The research method was survey. Singarimbun, et.al (1989: 3) defined survey as an investigation that explains existing factors and phenomena as well as provides factual information about an institution or social, economic and political situation taking place in an area. The data were divided into two, primary and secondary data.

The sampling technique was "two stage cluster sampling." First, the researcher selected two out of eight sub-districts in Parigi Moutong where shrimp farms are located. The second was to select two villages from two selected sub-districts because they applied the same type of technology (homogen). The samples were Dolago and Boyantongo villages in Parigi sub-district, and Tolai and Sausu Piore villages in Sausu sub-district. 
The bound of error was 0.1 and the formula to determine size of sample was as follows:

$$
n o=\left[\frac{\frac{Z \alpha}{2}}{2 \delta}\right]^{2}=\left(\frac{1.96}{2(0.1)}\right)^{2}=96.04
$$

Furthermore, $n o=96.04$ and the first equation became:

$$
n=\frac{n o}{1+\left(\frac{n o-1}{\mathrm{~N}}\right)}=\frac{96.04}{1+\left(\frac{96.04-1}{124}\right)}=54.25 \approx 54
$$

Using the level of significance $(\alpha)=0.05$ and bound of error $\delta=0.1$, out of 124 tiger shrimp farmers in the 4 (four) selected, the researchers selected 54 farmers as the sample. The proportional allocation formula was implemented to determine the distribution of sample from the 4 (four). Scheaffer, et.al (1990: 114) stated that proportional allocation is a method of determining size of a sample according to total number of population. The proportional allocation formula used was as follows:

$$
n i=\frac{N i}{N} \cdot n
$$

The respondents were 54 shrimp farmers who owned a shrimp farm in the selected location. Table 01 described number of samples involved from each of the villages.

Table 2 - Sample Description

\begin{tabular}{lllll}
\hline No & Sub-District & Village & Total Sample & Population \\
\hline 1. & Parigi & 1. Dolago & 15 & 34 \\
2. & Sausu & 2. Boyantongo & 11 & 25 \\
& & 1. Tolai & 13 & 30 \\
& & 2. Sausu Piore & 15 & 35 \\
\hline Total & & 54 & 124 \\
\hline
\end{tabular}

The data collection method, for both statements of problem, was multiple linear regressions.

\section{RESULTS AND DISCUSSION}

Farmer's age determines productivity because age is closely related to how much work shrimp farmers can do. Azwar (2002) and Soekartawi (1988) as cited in Purwantiningdyah (2003: 84) argued that individual characteristics, such as age, affect adoption of innovation. Adoption of innovation can be divided into four age groups, namely $20-35$ years old as early applicator, $36-45$ years old as initial applicator, $46-50$ years old as final applicator and over 50 years old as rejectors (Wiraatmaja 1984 in Sulaeman 2005: 76).

Based on the analysis 31 or 57.41 percents of the respondents were classified as both early applicator and final applicator, which means that they were aware of the importance of technology for tiger shrimp cultivation. Tiger shrimp cultivation requires rationale or logical thinking because it takes a serious management and a lot of capital to run a successful shrimp farm. The farmers should select how much seeds they will stock and when they should stock them very carefully.

Farmer's level of education will affect their ability and skills to receive innovation and absorb farming-related information. Well-educated farmers will accept, apply and even develop a new technology for developing their business more easily. 
The findings showed that $55.56 \%$ of the farmers graduated elementary or junior high school. In other words, their level of education was relatively low. Education plays pivotal role in farmers' ability to run their business professionally and use all resources they can access to increase production. Well-educated farmers had more chance to develop their business as they can accept innovation and use new advances of technology more easily.

Farming experience is closely related to farmer's action and thinking skills, which influence their interest, need and problem-solving methods (Gagne, 1967 as cited in Purwantiningdyah 2003: 87). Having heard about the most current trend in technology, a well-experienced farmer (year of farming became the indicator) would calculate business risk carefully and therefore, did not change their perspectives or methods as quickly without analyzing the technology.

The tiger shrimp farmers in Parigi Moutong are experienced farmers; $61.11 \%$ of the farmers have been running shrimp cultivation for more than 15 years. It showed that empirical evidence and effective methods are needed prior to changing their farming method.

The respondents started working at their parents' shrimp farm and had their own shrimp farm when they grew older. Thus, these farmers learned farming methods from their parents (a set of habitual concept passed between generations).

In the tiger shrimp farm in Parigi Moutong, the farmers applied advances of technology for: (1) shrimp pond reconstruction, (2) irrigation (water management), (3) soil management, fertilizer application and fish feed, (4) stocking, (5) pest and disease control, and (6) harvest and post-harvest. Criteria used to determine level of technology application for the tiger shrimp farm in Parigi Moutong are: (a) good (3), (b) fair (2), and (c) poor (1).

Based on the previous study (Yasin Muhammad, et.al: 2015) and the criteria, it can be concluded that $66.67 \%$ of the total 54 respondents had fair level of technology application and $33.33 \%$ had good level of technology application.

The shrimp farm had a low productivity because the farmers had very low stocking density. Neither farmers applied the traditional standardization of stocking density $(20,000-$ 60.000 shrimp/hectare/mt). Stocking density is one of the indicators of technology application. High stocking density requires a suitable and regular application of fish feed as well as regular application of water $\mathrm{pH}$, salinity, clarity (turbidity), oxygen content and temperature.

Based on the observation, the shrimp farmers in Parigi Moutong were using traditional technology or extensive Plus. The technology application was categorized as "traditional plus" because the farmers did not provide supplementary fish feed; they relied on natural fish feed. The observation also revealed that the farmers took very little risk as they were still applying "Intensifikasi Tambak (Intam) B1," a type of traditional polyculture intensification where shrimp and milkfish are kept in the same pond.

Having obtained the level of technology application in the tiger shrimp farm in Parigi Moutong, the researchers proceeded to investigating factors that influenced application of such conventional technology. There are three factors underlying implementation of the traditional technology, namely capital, training on agriculture and sales price.

The researchers used multiple regression analysis to investigate socio-economic dimensions that influence technology application in the shrimp farm. Table 3.01 showed result of the regression analysis.

Table 3 - Result of Multiple Regression Analysis

\begin{tabular}{c|c|c|c}
\hline Variable & Coefficient of Regression & Standard Error & $t_{\text {value }}$ \\
\hline Constant & 52.9312 & 7.1040 & 7.4508 \\
Financial Capital $\left(\mathrm{X}_{1}\right)$ & 0.3827 & 2.0631 & 0.1854 \\
Training on Agriculture $\left(\mathrm{X}_{2}\right)$ & 0.7571 & 0.2740 & 2.7628 \\
Sales Price $\left(\mathrm{X}_{3}\right)$ & 0.5721 & 0.6739 & 0.8494 \\
\hline
\end{tabular}

$F_{\text {value }}=3,592$

Coefficient of Correlation $(R)=0.6749$

Coefficient of Determination $\left(R^{2}\right)=0.4556$ 
The analysis showed that coefficient of determination $\left(R^{2}\right)$ was 0.4556 , which means $45.56 \%$ of technology application in the tiger shrimp farm in Parigi Moutong was influenced by variables inside the model, while the remaining was affected by variables outside the model.

$F$ value was 3.592 or higher than $F$ table $0.05(10 ; 43) 2.850$. Thus, it can be concluded that all of the independent variables had simultaneous influence towards technology application (Yi) when the level of confidence is 95\%. An increase or decrease in the independent variables would cause another increase or decrease in technology application. Result of the regression analysis on Table 4.28 can be transformed into the following equation:

$$
Y i=52.9312+0.3827 X_{6}+0.7571 X_{8}+0.5721 X_{10}+e_{i}
$$

The following procedure was to conduct t-test to investigate how much influence each independent variable had towards the dependent variable.

The statistical analysis conducted to investigate partial influence of financial capital $\left(\mathrm{X}_{1}\right)$ towards level of technology application $(\mathrm{Yi})$ showed that $\mathrm{t}$-value was 0.1854 , not significant at $95 \%$ level of confidence $(\alpha=0.05)=2.000$. Positive regression coefficient showed that there is a positive relationship between financial capital and the level of technology application. It implied that one point increase in financial capital will result in 0.3827 percent increase in technology application and one point decrease in financial capital will decrease the application of technology by 0.3827 percent.

The shrimp farmers in Parigi Moutong generally used their own money (one that they saved from previous harvests) and some loan from their family members and relatives. The tiger shrimp cultivation needs more capital (credit), but complicated bureaucracy prevented the farmers from getting loan from the banks.

The statistical analysis conducted to investigate partial influence of training on agriculture $\left(\mathrm{X}_{2}\right)$ towards level of technology application $(\mathrm{Yi})$ showed that $\mathrm{t}$-value was 2.7628 , significant at $95 \%$ level of confidence $(\alpha=0.05)=2.000$. Positive regression coefficient showed that there is a positive relationship between training on agriculture and the level of technology application. It implied that one point increase in training on agriculture will result in 0.7571 percent increase in technology application.

Based on the finding, it can be concluded that training on agriculture had pivotal role in increasing the farmers' knowledge and farming skills. Objective of the training is to develop the farmers' knowledge on advances of technology that increase their shrimp farm productivity.

Based on the field observation, $46.30 \%$ of the farmers rarely attended training on agriculture. Some farmers who joined a farmer's association attended routine agenda their farmer's association conducted.

The statistical analysis conducted to investigate partial influence of sales price $\left(\mathrm{X}_{3}\right)$ towards level of technology application $(\mathrm{Yi})$ showed that $\mathrm{t}$-value was 0.8489 , not significant at $95 \%$ level of confidence $(\alpha=0.05)=2.000$. Positive regression coefficient showed that there is a positive relationship between sales price and the level of technology application. It implied that a one rupiah-increase in sales price will result in 0.6739 percent increase in technology application.

Based on the explanation, tiger shrimp sales price has positive influence towards technology application; increasing sales price encourage the farmers to apply advances technology for their shrimp farm. Between 1998 and 1999, when US\$ 1 equals to 15,000 rupiahs, the shrimp price was 150,000 per kg. The farmers applied some technology by increasing stocking density, providing supplementary fish feed and other inputs.

The farmers sold their harvest for either 70,000 rupiahs $/ \mathrm{kg}$ in which one kilogram consisted of 20 to 30 shrimps or 50,000 rupiahs $/ \mathrm{kg}$ where one kilogram consisted of 30 to 40 shrimps. 22 respondents $(40.74 \%)$ stated that the pricing was low. Tiger shrimp sales price should be in line with international currency (US\$ against IDR) because tiger shrimp is an export commodity with high international demand. 


\section{CONCLUSION AND RECOMMENDATIONS}

Financial capital, training on agriculture and sales price have both simultaneous and partial influence towards technology application for tiger shrimp farm in Parigi Moutong;

Technology application has positive influence towards productivity of tiger shrimp farm in Parigi Moutong. Higher technology application will cause higher productivity.

Based on the conclusion, very little financial the tiger shrimp farmers in Parigi Moutong has leads to low technology application. Therefore, government should establish policy that helps farmers accessing financial capital more easily. In addition, fast and massive transfer of knowledge, for example assistance on well-planned shrimp cultivation, is needed to increase farmer's knowledge and skills on the current application of technology for tiger shrimp cultivation.

Another important factor is to make sure that sales price of the shrimps can cover the farmers' operational cost or even helps farmers gaining some profit. Therefore, the farmers can focus on their shrimp farm. The government should issue policy on reasonable tiger shrimp sales price.

\section{REFERENCES}

1. Amri K., 2003, Budidaya Udang Windu Secara Intensif. Depok, Agromedia Pustaka. Cohen, J.,1977, Statistical Power Analysis for the Behavior Science. Academy Press.

2. Dahuri, R., 2002, Membangun Kembali Perekonomian Indonesia Melalui Sektor Perikanan and Kelautan, Jakarta, LISPI.

3. Departemen Kelautan and Perikanan, 2006, Revitalisasi Perikanan Budidaya 2006-2009. Jakarta, DKP.

4. Dinas Perikanan and Kelautan Kabupaten Parigi Montong, 2008, Profil Sumberdaya Perikanan and Kelautan Kabupaten Parigi Montong. Parigi. Dinas Perikanan and Kelautan Kabupaten Parigi Montong.

5. Dinas Perikanan and Kelautan Provinsi Sulawesi Tengah, 2009, Laporan Tahunan. Palu, Dinas Perikanan and Kelautan Prov. Sul-Teng.

6. Direktorat Jenderal Perikanan Budidaya., 2002, Petunjuk Pelaksanaan Pembudidayaan Ikan (Inbudkan). Jakarta, Departemen Kelautan and Perikanan.

7. Ismuha, K. 1988, Faktor-faktor Yang Mempengaruhi Produksi Tambak Udang Windu di Kabupaten Aceh Besar. Bandung Tesis tidak dipublikasikan, Program Pascasarjana Universitas Padjadjaran.

8. Mardjudo, A. 2017, Household Economic Model to Improve Small- Scale Fisherman Income at Rural Manapadi (Rice-Fish System) Development Program in Donggala, Central Sulawesi. RJOAS, 10(70). DOI https://doi.org/10.18551/rjoas.2017-10.35

9. Purwantiningdyah, D.N.,2003, Faktor Internal and Eksternal yang Mempengaruhi Tingkat Penerapan Teknologi and Dampaknya Terhadap Produktivitas and Pendapatan Pada Usahatani Padi Sawah. Bandung, Tesis Tidak Dipublikasikan. Program Pascasarjana Universitas Padjadjaran Bandung.

10. Schiaffer, R.L. 1990, Elementary Survey Sampling (4th Ed.). California, Duxbury Press.

11. Singarimbun, M. \& Effendi, S, 1989, Metode Penelitian Survai. Jakarta, Lembaga Penelititan Pendidikan and Penerangan Ekonomi and Sosial (LP3ES).

12. Soekartawi. 1988, Prinsip Dasar Komunikasi Pertanian. Jakarta, Univarsitas Indonesia (UI-Press).

13. Sulaeman, 2005, Faktor-Faktor yang Mempengaruhi Tingkat Penerapan Teknologi and Produktivitas Usahatani Cabai Merah. Bandung, Tesis tidak dipublikasikan, Pascasarjana Universitas Padjadjaran Bandung.

14. Suyanto, S.R. 2003, "Budidaya Udang Windu", Penebar Swadaya, Jakarta.

15. Wicaksana, E. A., 2003, Analisis Strategi Pemasaran Produk Perikanan (Udang Wibdu Beku) PT. Inti Aqua Perdana. Tesis tidak dipublikasikan, Universitas Hasanuddin.

16. Yasin, M. \& Rahman, A. 2015, Analisis Tingkat Penerapan Teknologi Budidaya Udang di Kabupaten Parigi Moutong Provinsi Sulawesi Tengah. Jurnal IImiah AgriBA. 